\title{
CATALONIA AND SPAIN AT THE CROSSROADS: FINANCIAL AND ECONOMIC ASPECTS ${ }^{1}$
}

\author{
Antoni Castells \\ (Universitat de Barcelona)
}

\section{INTRODUCTION}

Although the economics of secession is still in its infancy (Spolaore, 2010; Bordignon, 2010) as a specific field of economics science, some very interesting contributions have been made in the last fifteen years about this issue. The general discussion focuses essentially in the trade off between the benefits of size versus the costs of heterogeneity. The precise equilibrium point of this trade-off depends on two factors: the international openness of the economy and the quality of democracy and of institutions (Alesina, 2003, Alesina and Spolaore, 1997 and 2003; Alesina e.a., 2005; Spolaore, 2010).

In a world of protectionism, where political borders suppose barriers to international trade, the size of the country is very important because it determines the size of the domestic market. However, as the empirical evidence generally confirms, the more there is a world of free trade and high economic integration, the more small countries can prosper. As Spolaore (2010) concludes: "In a nutshell, economic integration and political disintegration tend to go hand in hand".

The quality of political institutions and democracy is the other factor with a relevant influence in this trade off. The costs are not directly imposed by a large territorial heterogeneity in preferences, but by its translation into the field of political action. On the contrary, they are produced by homogeneous public policies provided with uniform rules from central governments.

Federalism and decentralisation can increase country stability and reduce the incentives to secede, but this depends on two essential factors: the degree of decentralisation and the quality of institutions. Decentralisation will reduce secessionism "if and only if decentralisation is above a given threshold" (Spolaore, 2010). The quality of decentralisation depends also strongly on the real political decision-making power allocated to intermediate (state, provincial, regional) governments; on their ability to effectively represent heterogeneous preferences; and on an institutional framework which could ensure the resolution of conflicts through negotiation and agreement.

The design of an institutional framework which is flexible enough to accommodate a heterogeneous society becomes, therefore, a crucial element. For example, according to Becker (2012) this was an essential factor for reducing the strength of the independence movement in Canada. An essential function of the institutional framework is to create a feeling of political community membership, without which it is very difficult to achieve country stability. Mentioning Bakke and Wibbels (2006), Bordignon (2010) outlines that "autonomy and redistribution within a country may help; but if there is no (...) feeling of belonging across the different peoples living in a

\footnotetext{
${ }^{1}$ This article is based on the paper delivered at the Conference on "Economic Aspects of Constitutional Change", University of Stirling, Edinburgh, 19th-20th September 2013. The author is grateful for the comments made by an anonymous referee. The only responsibility for any mistakes on this paper is fully assumed by the author.
} 
country, it is difficult for them to be enough". The economic arguments for secessionism are therefore very important, but the decisive ones might be of a fully political nature.

In some large European countries, in the last decades economic globalisation has gone hand in hand with a powerful trend to political decentralisation (this has been the case in: United Kingdom, France, Italy, Spain). In Spain, and after years of apparent stability, the relations between Catalonia and Spain are experiencing troubled times. Different scenarios are foreseeable, and the possibility of constitutional changes is not excluded. On the contrary, such changes are highly probable in some scenarios. This paper tries to make a contribution on this issue by examining particularly the main economic effects of both the staying together and the secession scenarios. Following this introduction, the second section reviews the main aspects of the relations between Catalonia and Spain. The third and fourth sections analyse different scenarios with a particular focus on the main issues that the secession scenario raises. The fifth section contains a concluding remark.

\section{THE RELATION CATALONIA/SPAIN: POLITICAL AND ECONOMIC ASPECTS}

\section{Some relevant figures}

Table 1 supplies some relevant data about the relative size and role of the Catalan economy within Spain. Catalonia has a population slightly above 7.5 million inhabitants, or $16.0 \%$ of the total Spanish population. The GDP was, in 2012, close to 200 billion Euros, or $18.9 \%$ of total Spanish GDP.

The GDP per capita of Catalonia (26.319.5 Euros) is around 20\% higher than the Spanish average. It is 116.9 of EU average (in purchasing power parity) and 106.7, considering the EU-15 (before the enlargement to the Eastern countries). For Spain, the respective figures are 97.7 and 89.0.

The productive structure of Catalonia shows also some particularities. The Catalan economy is both more industry-focused and more open than the rest of Spain. Even if the economic crisis has produced devastating effects in industrial employment, industry contribution to total GDP is almost 4 points higher in Catalonia than in Spain $(19.2 \%$ vs. $15.5 \%)$.

The Catalan economy is also, by far, a significantly more open economy than the Spanish one. Catalan exports of goods (services excluded) represent $26.2 \%$ of total Spanish exports. Exports of goods represent almost thirty per cent $(29.4 \%)$ of Catalan GDP, while they represent $19.3 \%$ of the rest of Spain (excluding Catalonia). Also in the tourism sector (by far, the most important service in exports), Catalonia leads the Spanish economy. It receives around $25 \%$ of all foreign tourists visiting Spain. In turn, Spain is amongst the top three countries in the world in this economic activity.

Even if the fundamentals show potential for successful reforms and, thus, for growth and employment, the current situation is still very worrying. The Spanish and Catalan economy are in the midst of a very profound crisis and have been in recession for many quarters. The rate of unemployment is extremely high $(22,3 \%$ for Catalonia and $26,0 \%$ for Spain,). The imbalances that are at the root of the crisis in Catalonia are very similar to the Spanish ones: extreme over-indebtedness in the private sector, a housing bubble, troubles in the financial system, significant current account deficit, and a fall in competitiveness which is in turn mainly due to a sharp increase in unit labour costs prior to the crisis. 
Some of these imbalances have been very drastically and positively corrected in the last years, in particular the current account deficit and the recovery of competitiveness. But in some other areas we are still just in the middle of the road, and, very especially concerning unemployment, the task ahead is still very hard.

The democratic Constitution of 1978: Some historical and political background and the creation of the 'State of the Autonomies'

The historic problem of integration of Catalonia within the Spanish state exists, at least, since the eighteenth century, after the Succession War, a conflict in which many European countries were involved. One of the main reasons for the difficulties in integrating Catalonia within Spain is the historical asymmetry between political power and economic power in Spain. The centre (Castille) has historically had political and military power, while the periphery (Catalonia and Basque Country) have had the economic power.

In contrast with what happened in other countries, in Spain, nation state and national market did not go hand to hand. Economic weakness didn't allow the centre to perform the process of 'national' assimilation of former 'peripheral' nations and cultures that took place in other countries and the creation of a national market as a powerful and effective nation-maker. In Spain, the so called 'peripheral nations' survived. It could be said that $\mathrm{n}$ some way Spain has always been a frustrated nation state.

In the second half of the nineteenth century, as Catalonia emerged as a powerful industrial region leading the Spanish economy, a political movement of national affirmation arose with special strength: 'Catalanism'. 'Catalanism' had two basic goals: to achieve the self-government and the acknowledgement of Catalonia as a nation; and to transform and modernise the Spanish state, making it able to provide the needs an industrial society required.

'Catalanism' has been a transversal, large movement that for most than a century and a half has occupied the mainstream of Catalan politics (both at the right and at the left of the political spectrum). In the short periods of autonomy and democracy before the 1936-1939 Civil War (in the 1910's and in the 1930's during the Second Republic), and since 1977, with the establishment of a democratic monarchy after the death of Franco, 'Catalanist' parties have won all the elections held in Catalonia.

After the Franco's dictatorship, the democratic Constitution of 1978 seemed to put an end to the historic problem of integration of peripheral nations (especially Catalonia and the Basque Country) in Spain. The main Catalan parties played an essential role in its elaboration. In a sense, the Constitution contained an implicit agreement: mainstream 'Catalanists' parties renounced to their ultimate aspirations for secessionism, and the main democratic Spanish forces to the 'renaissance' of the traditional Spanish state: unitary, strongly centralised and deeply impregnated of Spanish nationalism.

The Constitution of 1978 established what has been called 'the State of Autonomies', with the creation of the Autonomous Communities, an intermediate level of government with a legislative assembly. In that moment the acceptance of self-government was seen as a historical step.

To obtain an agreement on the nature of peripheral countries, the Constitution introduced what was then considered a very important distinction between nationalities and regions. The Constitution distinguished, too, between two types of Autonomous Communities, regarding the range and level of responsibilities they could assume, and 
also the speed in becoming one. As a matter of fact, when the Constitution was approved in 1978 it was not expected that the most common model for all regions would be to become Autonomous Communities, but rather a framework with a quite specific and differentiated treatment in the historic regions of Catalonia and the Basque Country (and, to a lesser extent, Galicia).

However, in practice the autonomy was spread to all Spanish regions in similar terms, with the very important exception of the specific financial regimes applied to the Basque Country and Navarra. The generalisation of autonomy did in fact lead to a watering down of the quality and intensity of responsibilities and resources at the Autonomous Community level of Government. In fact in Catalonia the degree of selfgovernment that was obtained did not meet previous expectations.

The Constitution granted nonetheless stability for a period of about twenty years (19802000). Catalonia has at present an autonomous government with a huge budget, a Parliament, and direct responsibilities in the delivery of basic public services. However, financial and economic problems were always present in some crucial areas: the delimitation of responsibilities, the financing system of the autonomy and the allocation of central government expenditures (notably, infrastructures) in Catalonia.

The 'Statute of Autonomy' of Catalonia (the by-Constitution that sets up the rules and institutions of the self-government of Catalonia) was enacted in 1979, and the first Catalan elections took place in 1980. Since then, a large process of devolution of responsibilities from the central government to the autonomous governments occurred. The Autonomous Communities represented in 2010 the $34.6 \%$ of the total expenditure of the public sector (Table 2), a very significant figure, higher than in many federal countries.

In quantitative terms, the key responsibilities of autonomous governments are health and education. Table 3 shows the distribution of expenditure for the government of Catalonia. In 2012 it reached 37.5 billion euros, (around $18.75 \%$ of GDP). Health represented $23.8 \%$ of all public expenditure and education $14.8 \%$. The government of Catalonia is fully responsible for the provision of these essential public services, although key regulations on standard of service are decided by central government. In 2012, the effects of the recession and the public deficits resulted in the expenditure related to the debt burden soaring to the $14.8 \%$ of the total. This figure includes all kind of financial debt, mostly bonds issued by the Catalan government in its own name. This debt does not have the backing of central government, although the latter must authorise any new issuance of autonomic debt, in line with its 'Annual Borrowing Plan'. In general, the responsibilities are very similar across Autonomous Communities, although Catalonia has a special status in some particular fields, such as Police and Justice which jointly represent $5.4 \%$ of total expenditure.

In general, in different public policy areas there is not an exclusive allocation of responsibilities to one single level of government, but rather different governments share concurrently some degree of responsibilities with different vertical powers. For example, it is very usual that the central government has the power to pass a basic law, and autonomous governments to pass second level laws and exercise executive powers. Therefore, a relatively high budget doesn't necessarily mean an equally high political power in decision making in any functional field of responsibility.

In a way, in many fields, the Autonomous Communities have low quality responsibilities, of a rather more administrative than political nature. This is mostly the result of an ambiguous and insufficient constitutional design, but also of the 
interpretation made by the Constitutional Court about the room and power that the Constitution allows to Autonomous Communities.

\section{Financing Autonomous Communities}

The essential traits of the finances of autonomous communities have evolved considerably throughout the years. In the early days their revenues were essentially grants from the central government, by an amount equivalent to the expenditure transferred (and whose value was calculated through a rather complex and administrative procedure). Over time the system was slowly improved in different aspects. At present every five years a negotiation takes place between central government and all Autonomous Communities and as a result some changes are introduced into the system.

Table 4 shows the current distribution of resources for the government of Catalonia (for a detailed analysis and description, see Vilalta, 2013). After the last reform, in 2009, $73 \%$ of total revenue comes from taxes, $8 \%$ from grants, and around $18 \%$ are other revenue. Three big categories of taxes can be established. Firstly, own taxes, which are not very relevant in overall revenue terms as they represent $1.6 \%$. The second group are totally ceded taxes (created for the central government, which establishes their basic elements), and represent around $15 \%$ of total taxes. The Autonomous Communities have some normative responsibility (which can be very large, especially when deciding the tax rate), receive all the yields coming from these taxes and also have administrative responsibility to collect them.

The third group are shared taxes, which represent around $82.7 \%$ of total taxes and $61 \%$ of total revenue. The revenues produced by the main taxes of the fiscal system, excluding corporate tax, are shared between central government and autonomous governments: personal income tax (50\%-50\%), value added tax (50\%-50\%) and excises $(58 \%-42 \%)$, for Autonomous Communities and central government, respectively.

Grants from the central government represent less than $10 \%$ of total revenue of the government of Catalonia. Their structure is complex and the result of a history of permanent changes that led to the current situation where three main funds exist.

The so-called 'Fundamental Public Services Guarantee Fund' is a horizontal partial equalisation mechanism. The autonomous governments put in a common pool the $75 \%$ of their potential tax capacity, and the total amount is distributed between all the autonomous communities according to their population adjusted by needs. The most prosperous autonomous communities, such as Catalonia, have a negative grant to be brought to the pool, and the poorest ones, a positive grant coming from this horizontal mechanism.

The other two funds, the 'Global Sufficiency Fund' and the 'Competitiveness Fund', are funded by central government. The former was designed as a guarantee so that all autonomous communities at least maintained the same level of revenue obtained with the previous mechanism. The 'Competitiveness Fund' is in fact a sub-fund of a broader fund called 'Cooperation Fund'. This Fund was set up in the 2009 reform, and it is allocated to the regions where the difference between 'fiscal capacity' (how much they contribute to the 'common pool') and revenue (how much they receive) is larger.

Autonomous public deficit and debt were relatively controlled until the economic crisis started in 2008. In 2007 debt represented an $8.0 \%$ of GDP. However, this figure soared with the recession to more than $25 \%$ in 2012 . 
There have always been statutory limits for the public deficit, borrowing and indebtedness levels of Autonomous Communities. The Spanish Parliament establishes every year the public deficit targets of different levels of government. In the case of autonomous governments, these are decided on the basis of a proposal previously agreed by the 'Fiscal and Financial Policy Council', a body where financial ministers of both central and autonomous governments sit together. The limitations have severely hardened in the last years because of both European and Spanish new regulations resulting from the fiscal consolidation policies.

The financing system of the Generalitat has been a permanent cause of struggle between Catalonia and Spain; this is because it provides only a limited power to decide over the taxes that are paid in Catalonia (low quality of fiscal responsibility) and also because the amount received is considered unsatisfactory.

This is in turn mainly attributed to the excessive solidarity produced by a system that leads to over equalisation. Table 5 shows the effects of implicit and explicit perequation mechanisms contained in the financing system of autonomous communities. While Catalan citizens make a tax contribution per capita to the funding of total autonomous governments that is $20 \%$ above the average, the resources per capita available for the Catalan government are around the average. Catalonia is ranked third out of fifteen Autonomous Communities in terms of tax contribution per capita (i.e., before equalisation) and only ninth in terms of autonomous resources per capita (i.e., after equalisation). The effects of the equalization can vary from one year to the next, according the variation of variables that determine tax contribution (essentially tax bases) and of variables that determine revenues (essentially population and other expenditure needs).

The new model implementing the new Statute of Autonomy passed in 2009, and meant an important change for Catalonia. Before that year, the position of Catalonia in terms of revenues per capita was 94 (being 100 the average of all Autonomous Communities). Immediately after the reform (2009), it moved to 102.3 (and to 103.6 considering adjusted population) and then it went down again to 99.4 in 2011 (Table 5).

\section{ECONOMIC AND FINANCIAL IMPLICATIONS OF CONSTITUTIONAL CHANGES IN THE RELATIONSHIP BETWEEN CATALONIA AND SPAIN (I): THE STAYING TOGETHER SCENARIOS}

\section{The break-up of the constitutional pact and possible scenarios ahead}

The relationship between Catalonia and Spain is currently nearing the end of the cycle that started during the transition, period that lapsed from de dictatorship to the democracy, and especially with the democratic Constitution of 1978. Many reasons have led to a progressive deterioration of the Constitutional agreement. The most remarkable one is probably the failure in approving a new 'Statute of Autonomy' (the by-constitution of Catalonia) in the second half of the 2000's. Although the 'Statute of Autonomy' was not abrogated, some of its essential aspects were eliminated or interpreted in a very restrictive way. A large majority of Catalans do not consider the Constitution as the appropriate framework for self-government since the Constitutional Court declared the Statute of Autonomy for Catalonia unconstitutional in 2010.

At present the underlying forces that during the transition converged into the constitutional pact have strongly reversed their sign. The Constitution was the result of a political pact between the democratic opposition, reformists from Franco's establishment and democratic nationalists from Catalonia and the Basque Country. An 
essential element of this pact (as indicated in the second point of the second section) was the acknowledgement of self-government for the usually called 'peripheral nations'. Nowadays, a general perception exists in Spain that the 'State of Autonomies' has gone too far, and that it has to be corrected by centralising more. On the other hand, in Catalonia the opposite perception exists that it is very difficult to find the solution for the problems facing Catalan society within Spain. Sovereignism now is in the mainstream of Catalan politics. Currently, the main point of the agenda in Catalonia is to hold a referendum in which the Catalan people could decide on the link between Catalonia and Spain.

So far, the positions about the referendum are deeply opposed: while it is backed by nearly eighty per cent of Catalan society, the central government is not planning to allow that a referendum is held, on the basis that it is forbidden by the Constitution. At this point in time the real struggle is not yet for independence but for the referendum on self-determination (which is called 'the right to decide'). In fact, there are political parties which are pro referendum but not pro-independence.

In this context, in theory, four hypothetical scenarios can be envisaged [there is some similarity with the scenarios mentioned by Vaillancourt (2010) for the Québec/Canada case]. All they imply either a formal or an implicit constitutional change.

Going from more to less centralisation, the first scenario would be the 'Spanish nationalist' involution. This scenario in turn contains two sub-scenarios, a strong involution leading to a centralist revision of the constitutional framework; and a 'soft' involution, in line with the restrictive interpretation of constitutional precepts already made in the last years. The second scenario would be a constitutional reform that introduced some kind of generalised and explicit federalism. The third one would be a specific and bilateral deal for Catalonia within Spain. The fourth scenario is the secession, which also contains two sub-scenarios, depending on whether secession leads Catalonia to be within or outside the European Union.

It is not the purpose of this paper to assess the probabilities of each of these scenarios or to analyse their political aspects. What matters for the purposes of this paper is that all of them are reasonably likely, all of them imply constitutional changes, and that these changes would have economic and financial consequences which should be studied.

In the next sections, we will limit this analysis to two basic scenarios: the staying together scenarios (which include the federalist and the special deal for Catalonia ones) and the secession scenario (with its two sub-scenarios). We do not analyse the implications of the centralist revision scenario - essentially, because it is not a real solution to the conflict. In addition, the scenario would in many respects not be that different from the current situation.

\section{Staying together scenarios: Financial implications of constitutional changes}

Over the years many proposals, papers and reports have been issued about how to improve the economic and financial aspects of both the 'State of Autonomies' and the specific situation of Catalonia. This section is therefore shorter than the next one, where we are obliged to enter the significantly less explored territory of the economic aspects of secession.

As we just mentioned, two basic scenarios could be considered in the staying together alternative, both implying constitutional changes: a generalised federalist option and a singular deal for Catalonia. The agenda of the federalist option is quite well known. 
Regarding its economic and financial aspects, it could be summed up in four main points.

The first one is fiscal responsibility. The essential principle is that spending of Autonomous Governments should be largely funded by taxes levied by these governments and not by grants coming from central government. In addition, they should have both normative and administrative responsibility for these taxes, although it is well known that in some taxes (corporate tax, VAT) large limitations exist for having full fiscal sovereignty. In the Spanish case, there is significant scope to improve the present situation.

The second point is equalisation. Most federal countries have explicit perequation systems. An explicit partial equalisation mechanism was adopted in Spain in 2009. But the reform was so cautious and contained so many safeguards that its effects have not been satisfactory. As Table 5 shows, the system still produces a strong over equalisation. There is therefore still plenty of scope for introducing further substantial improvements.

The third point concerns redressing vertical fiscal imbalances (i.e., the ratio potential revenues/expenditure needs for central government is much larger than for autonomous governments). A new system should involve matching expenditure needs with potential tax resources across all Autonomous Communities. As part of that new system the current vertical imbalance in favour of the central government should be corrected. Furthermore, some regular mechanism should be provided for updating the balance between relative tax potential and relative expenditures needs of Autonomous Communities and the central government.

Finally, the fourth point is the participation of Autonomous Governments in decisionmaking by the state. A large part of tax and economic regulation as well as basic laws and economic decisions affecting autonomous responsibilities are undertaken at the state level. The actual autonomy of territorial governments is limited by this constraint. In some countries, this imbalance is partially corrected with an upper legislative chamber (the senate) which represents territorial interests. While different implementations are possible (for example, the German and United States formulae are quite different), the principle is the same. Some attempts have been made in Spain for reforming the Senate in this way, but the results so far have been disappointing.

This scenario of constitutional change could use as a guide the models of federal countries with similar political, economic and social characteristics (i.e., Canada, Germany, Switzerland and the United States; maybe also Austria and Australia), although these certainly are all very different in many aspects. In general terms, these are the four points that could constitute the core of an agenda for a federal reform of the Constitution. A large consensus exists on the principles, less so on details and on their implementation.

The problem is not therefore a lack of a proven model but the will to move toward a truly federal system. The Spanish system is a hybrid between a unitary system, with more administrative than political decentralisation, and a federal system biased towards the central government. Probably the failure of the process of the Statute of Autonomy of Catalonia (which was basically inspired by this model) has left this scenario deadly wounded. It is very likely that the time for a generalised federal solution in Spain is over.

Another possible scenario has to be considered within the staying together alternative. This is the scenario of a special deal for Catalonia. One of the most decisive reasons 
for the current uneasiness in Catalonia is the permanent comparison with the much more favourable results obtained by the special financing system of the Basque Country ('Concierto'). The Basque government has full responsibility for the collection of all taxes (including VAT and corporate tax). An amount is returned to the state ('cupo') to compensate central government for the provision of general services in the region. It has to be remarked that the last proposal coming from Catalonia to reform the financing system (the so-called 'Fiscal Pact') was clearly inspired by the system used for the Basque Country), and was presented to the central government in September 2012 with a very large support of political forces and civil society.

Nowadays, the situation is not the same. In Catalonia, the tempos have accelerated, secessionism has soared and it will probably be difficult to obtain again general public support for the proposal that was rejected by the central government in 2012 . The main point of the agenda at present is none other than holding a referendum to decide on the link between Catalonia and Spain.

It should not however be fully excluded that new options could appear in the course of the struggle to celebrate a referendum. One of them could be a special deal for Catalonia within Spain. The possibility that such a deal could be acceptable will depend on two key aspects: its contents and the guarantees of its fulfilment.

At the moment, given the turn of events, it is difficult to conceive that this deal could be limited only to financial aspects. The political aspects have become decisive. Although it is not the goal of this contribution to analyse the potential content of this deal, there are three points that are probably essential. The first one is the acknowledgement of the right of self-determination, i.e. the right to leave. In fact, a referendum could be held on this special deal rather than secession, with the deal probably containing the right to leave. Secondly, there is the essential point of language. Catalan people, whether they speak Catalan or Castilian, don't perceive the existence of a linguistic problem in Catalan society, where bilingualism is the norm. However, the permanent hostility of a large part of Spanish media and a flurry of decisions against the status of the Catalan language by the Spanish central courts are seen as a real threat. It is therefore very probable that an agreement would not be possible if it does not include the full transfer of linguistic responsibilities to the government of Catalonia.

Thirdly, there are the economic and financial aspects. These concern three main questions: the adoption of an allocation rule for central government expenditure (infrastructures, especially) in Catalonia (similar to the one included in the Statute of Autonomy and later watered down by the decision of the Constitutional Court); the real scope for the Generalitat to have effective decision-making power on crucial points for the Catalan economy; and finally the financing system for the Generalitat of Catalonia. In this specific field, a federally inspired model, along the lines of the one just described, could probably be acceptable as long as it satisfies two basic points: a large fiscal autonomy both on normative and administrative matters; and a limited equalisation.

In summary, the alternative of staying together contains two scenarios: a reform of the Constitution with generalised federalist inspiration or a special deal for Catalonia. Both scenarios would imply constitutional reforms.

IV. ECONOMIC AND FINANCIAL IMPLICATIONS OF CONSTITUTIONAL CHANGES IN THE RELATIONSHIP BETWEEN CATALONIA AND SPAIN (II): THE SECESSION SCENARIO 


\section{Main issues}

Another alternative is secession. The debate about the economic and financial viability of an independent Catalonia has to date mainly focused on the trade off between the fiscal benefits of eliminating negative fiscal flows with the rest of Spain, and the losses from a potential decline of sales to the Spanish market, the main trade partner of the Catalan economy.

More research is especially needed in two fields. First of all, the application of some of the most relevant theoretical models to the Catalan case would be very useful. For instance, according to Spolaore (2010), the two decisive variables (for determining the exact point of the 'trade off' between costs and benefits of secession) are the degree of openness of the economy and the ability of institutions to deal with heterogeneity. The second point to be investigated should be which economic policies benefiting Catalan economy that are not adopted at the present by central government could be pursuit by an independent Catalonia, and which would be their impact in terms of GDP growth.

These are, certainly, key points. The purpose of this paper is, however, more modest. It tries to examine the state of the present debate, and the economic arguments that are being exposed pro and con the independence of Catalonia.

This is why the impact on Catalan exports to the rest of Spain and the fiscal flows are probably the two main issues that need to be carefully examined in the secession scenario. However, other crucial points also deserve to be studied: the potential economic benefits from having the power to make political decisions; the costs of a potential exit from the European Union and the Euro zone; the effects of the fragmentation of the Spanish market; and the allocation of a share of the debts and assets of the Spanish state.

\section{Catalan exports to the rest of Spain}

The Spanish market is still the first customer for Catalan exports, although it has increasingly lost importance over time, especially since Spain joined the EU. One of the most crucial questions in the case of secession is its effect on Catalan exports to the rest of Spain and its consequences for Catalan GDP.

One of the most frequently mentioned 'pros and cons' in this debate is, undoubtedly the 'border effect'. It has been studied by many authors (MacCallum, 1995; Anderson and Van Wincoop, 2001; Eaton and Kortun, 2002; Ghemawat, 2011a and b). The border effect predicts that the mere existence of a border significantly reduces trade between two territories due to historical links, similar regulations, language, and more similar tastes. The empirical calculations confirm this theory, but provide significantly different views as to the strength of the effect.

Rodríguez Mora (2012) provides an empirical approach to assess the border effect in the case of separation of Catalonia from Spain. It is based on the assumption that the border effect would reduce the intensity of trade between Catalonia and Spain to the same levels that it has between Portugal and Spain (80\% lower). According to these results, the secession of Catalonia would produce a reduction of $3.3 \%$ of the joint GDP of Catalonia and Spain, consisting of a $9 \%$ decrease in Catalan GDP and a $2 \%$ decrease in the Spanish one.

Paluzie (2010), Guinjoan and Cuadras (2011 and 2012), Cuadras (2012), Antràs (2012), Antràs and Ventura (2012), Amat (2013), strongly disagree with these estimates, which they consider to be overstatements. According to them, the effect on 
the GDP of Catalonia of the potential loss of a part of the Spanish market would be much lower than this $9 \%$. This is based on several arguments.

First of all, the border effect is a long term effect. It is the fruit of many years of history, and it is not an acceptable assumption to presume that the trade flows between Catalonia and Spain would suddenly structurally decrease to the levels of the ones between Portugal and Spain.

Secondly, according to the latest available data (2011), the destination of goods (not including services) produced in Catalonia is as follows: The Catalan market absorbs $26.7 \%$ of total sales, the Spanish market $34.5 \%$ and the rest of the world $38.8 \%$. However, even if the Spanish market is, by far, the first country destination for Catalan exports, its share has been sharply decreasing over time, as the Catalan economy has opened to international markets, mainly to the EU. While Spain accounted for $47.1 \%$ of Catalan exports (i.e., excluding the sales to the Catalan domestic market) in 2011 (and the rest of the world for 52.9\%), it accounted for 63.5\% in 1995 (and the rest of the world for $36.5 \%$ ). Thus, in sixteen years, the share of the Spanish market in Catalan exports has declined by 16.4 points. Spain has strongly lost importance for the Catalan economy compared to the rest of the world, both because the Spanish market has decreased as a destination for Catalan exports and because, even if the sign of the commercial flows is still positive for Catalonia, the percentage has sharply decreased over the years. An existing long term trend has been reinforced by the crisis of the last few years.

A third argument is that the impact of the reduction of exports on GDP is not direct. Exports are measured as sales to the rest of the world, while GDP is calculated in terms of added value. The conversion of a hypothetical reduction of exports to GDP is not automatic. It depends on how far the exports have been produced in Catalonia, or if they incorporate a significant fraction of imported intermediate goods. The estimation is, thus, relatively complex and requires using Input-Output tables. Guinjoan and Cuadras (2011) have shown that a fall of exports from Catalonia to Spain (measured as a percentage of GDP) has a transmission effect of two third in terms of GDP.

Considering all these points, these authors have estimated the impact of the reduction of exports to the Spanish market on the GDP of Catalonia. According to an extreme scenario (a reduction of $50 \%$ of consumption goods exports and of $20 \%$ of sales to firms), the impact in terms of a reduction of the GDP of Catalonia would be in a range between $1.7 \% / 2.2 \%$. They remark that this would be a very negative but not very probable scenario.

They point out, for example, that during the boycott campaign against Catalan products in 2005, during the discussion of the new Statute of Autonomy, the reduction of sales of Catalan products was around $5 \%$, so the hypothesis of $50 \%$ is an extreme one. In more moderate scenarios, these authors conclude that the fall of Catalan GDP could be in a range between $1.2 \% / 1.6 \%$, and in more favourable scenarios, even below $1 \%$.

\section{Fiscal flows with the rest of Spain}

Fiscal flows between Catalonia and the rest of Spain have been the subject of controversy for a long time. There is a long tradition of calculations and estimations of the difference between the central tax burden and central government spending allocated to Catalonia, i.e. Catalonia's fiscal deficit (see, among many others, Trias Fargas,1960; Petit Fontseré, 1965; Ros Hombravella and Montserrat, 1967; Castells, 1979 and 1998; Castells and Parellada, 1983a and b; Baró and Bosch, 1996; Castells, Barberán, Bosch, Espasa, Rodrigo and Ruiz-Huerta, 2000). 
Although these are methodologically complex estimations reliable estimates are currently available. Both the Spanish and the Generalitat of Catalonia governments have produced calculations in the last few years. They use two different approaches to calculate the allocation of central government expenditure: the cash-flow approach, which allocates the central government expenditure to the territories where the spending is made; and the benefit approach, which allocates the expenditure to territories according to who receives the services. According to the first approach, central institutions and general services placed in Madrid, some of them linked to the provision of pure public goods are allocated to only this territory, while according to the benefit approach, the expenditure is distributed over all the territories according to some indicator (normally, population).

The Departament d'Economia i Finances (Generalitat de Catalunya) (2008) and Ministerio de Economía y Hacienda (2008) estimates for the year 2005 (the only comparable ones) are reasonably similar. According to the cash-flow approach, the fiscal deficit of Catalonia (negative fiscal flows with the rest of Spain) was equivalent to $9.8 \%$ of GDP (Generalitat of Catalonia estimation) and to $8.7 \%$ of GDP (Spanish government estimation). According to the benefit approach, the fiscal deficit was $7.4 \%$ of GDP (Generalitat of Catalonia estimation) and 6.5\% of GDP (Spanish government estimation). Even if it could appear confusing, the term 'fiscal deficit' is commonly used in the fiscal federalism literature when the taxes paid by the citizens of a territory to the central government are higher than the central government expenditure in this territory. The explanation is that the money that leaves the territory is more than the money that comes in.

The Spanish government has not published further estimates. The Generalitat of Catalonia has regularly published theirs. The last one dates from 2013 and covers the period 2005-2010 (Table 6). The Table provides six different calculations. First of all, for each approach (cash-flow or benefit), there are two possibilities, depending on whether the central budget is 'neutralised' by the cycle or not i.e. depending on whether the allocation of revenues and expenditures is made 'as if' the central government budget was balanced. The reason to do this is to correct for the effect of the central budget deficit (or surplus). The deficit could distort results, since in years of central budget deficit it would hypothetically be possible that the net fiscal flows were positive for all Autonomous Communities. The 'neutralisation' alternative allows for two further possibilities, depending on whether the 'neutralisation' is made using total expenditures or total revenues.

There are therefore six different estimates, shown in Table 6. According to them, in the year 2010 the fiscal deficit of Catalonia amounted to $3.0 \%$ of GDP (cash-flow approach) and to $0.4 \%$ (benefit approach), without 'neutralising' the central government deficit. However, in this year this one was very large, so the results change a lot when it is 'neutralised': the fiscal deficit becomes $8.5 \%$ (cash-flow approach) and $5.8 \%$ (benefit approach) using total expenditure and $7.0 \%$ (cash-flow approach) and $4.8 \%$ (benefit approach) using total revenue.

These are the results. The estimates are relatively robust, and the methodology and even the results are not generally contested. Problems arise, however, with the interpretation of these figures, and in particular when it comes to choose the "most valid" approach. Which approach is better, the cash-flow approach or the benefit approach? Should the central budget be 'neutralised' or is it better not to do it? And in case of neutralisation, which should be the total amount used for the procedure: expenditure or revenues of the central government? 
The answer to all these questions should certainly depend on the issue we are analysing. As we are speaking of the potential fiscal benefits of the secession of Catalonia, which is a sensitive point, it is sometimes very difficult to avoid the interference of emotional positions. So, for those who are absolutely against the independence of Catalonia, the fiscal deficit of Catalonia is, without discussion, only $0.4 \%$ of GDP (benefit approach, without 'neutralising'), while for those who are clearly for secession the only valid figure is $8.5 \%$ (cash-flow approach, 'neutralising' for total expenditure) (see, among others, De la Fuente, 2012; De la Fuente and Rodríguez Mora, 2012; Sala-i-Martin, 2012b; Zabalza, 2012 and 2013; López-Casanovas, 2013). Unfortunately, in this area it is not generally the case that the figures or their scientific interpretation determines the political positions, but rather the opposite. There are predetermined political positions which lead to choosing the figure which is more convenient to support the pre established position.

The academic community should try to introduce some rationality when analysing these figures, even if it is difficult in this very politically biased context. It could therefore be useful to consider some points.

First of all, when considering the 'neutralisation' issue (should the allocation of expenditures and revenues be made 'as if' the central government budget was balanced?), it is necessary to distinguish between the short term and the long term effects. Assuming that the central budget is balanced along the cycle, the structural (or permanent) effect of eliminating the fiscal flows with the rest of Spain (long term effect) is better caught by the 'neutralised' figures. For the short term effects, the nonneutralised figures are more suitable, since the immediate impact on the GDP and on the Catalan public finances would be according to the currently observed fiscal flows.

It is therefore true that an independent Catalonia could have more solid and sustainable finances over time. But it is very misleading to claim that in this independent Catalonia all the financial problems of the Generalitat would disappear overnight.

Secondly, the cash-flow and the benefit approaches explain different issues and give answer to different questions. The benefit approach is more suitable if the objective is to estimate the impact on the reduction of the public deficit (of the government of Catalonia). The reason is that if Catalonia became an independent country, a part of the central expenditure not currently allocated in Catalonia should be assumed by the government of Catalonia. On the other hand, the cash-flow approach is the appropriate one if the objective is to study the impact on the total GDP of Catalonia. This is because, even if the government of Catalonia assumed new expenses, the money would not flow abroad as is currently happening, but would remain in Catalonia (Sala-iMartin, 2012b).

A third question is around how to implement the 'neutralisation', either via expenditure or via revenues. The neutralisation intends to determine the total amount of a balanced structural budget once the cyclical effects both on the expenditure and on the revenue side are removed. In normal times it could be assumed that revenues are more sensitive to the cycle while expenditures have a more persistent path. Thus, we could assume that variations in revenues are mostly responsible for public deficits and surpluses, and that, finally, along the cycle, revenues tend to adjust to expenditure. In this case, the total amount of expenditure would be the right figure for the 'neutralisation' procedure.

But these are not normal times, because the Spanish public sector is in a process of fiscal consolidation, with the aim of reducing structural expenditure. In this case, the 
total amount of expenditure is probably not the best figure to use, and a more accurate estimate (perhaps an intermediate point between total expenditure and total revenue) should be used.

In summary, in the long term, we can expect a positive impact in terms of public finances of between $4.8 \%$ and $5.8 \%$ of GDP and a positive impact on GDP between $7.0 \%$ and $8.5 \%$ (note that in both cases this is a one-off impact). The impact is lower in the short term: around $0.4 \%$ in terms of public finances (this would be the effective immediate reduction of the Generalitat of Catalonia public deficit) and around $3.0 \%$ in terms of the one-off impact on GDP.

\section{Some further strategic issues}

\section{1) Economic performance and political decision-making power}

One of the most permanent criticisms of Catalan society regarding central power is that the economic model conceived by the Spanish state has traditionally been a centralist, radial, Madrid-based model. This has been a harmful model for Catalan economic interests.

When assessing the pros and cons of secession it is important to consider the potential positive effect from gaining more political decision-making power for taking the economic decisions that the Catalan economy needs. This point has been stressed by many authors, in particular regarding infrastructure policy, but also the design of institutions, and the implementation of public policies and regulatory frameworks (Paluzie, 2010; Cuadras, 2012; Sala-i-Martin 2012b: Galí, 2012; Antràs and Ventura, 2012; Tugores, 2013).

It would therefore be important to understand better how far this factor could increase the trend growth rate of Catalan GDP. That is, how far it could increase the slope of the GDP line over time. Unlike the elimination of the negative fiscal flow, which has a oneoff effect, this one is a permanent effect For instance, if the 'normal' rate of growth of GDP was $2 \%$, and the 'capacity of decision power' moved this rate to $2.5 \%$, the effect on the Catalan GDP would be equivalent to the elimination of a fiscal deficit of $8.0 \%$ of GDP in the year zero after 15.7 years.

The economic model implicitly or explicitly fostered by the central government is a radial, Madrid-based model. In some strategic aspects, for example, airports, rail transportation, and regulation policy, it is therefore not difficult to speculate with the positive effects for the Catalan economy of having a direct decision-making power. Further research is needed, however, to obtain estimates of he effects of these policies on the potential growth rate of the GDP.

\section{2) The EU and Euro zone membership}

One decisive point is what would happen in relation to the membership of Catalonia in the European Union and the Euro zone. Probably, whether an independent Catalonia was a formal member of the EU or not, everybody would be interested in keeping the conditions of the single market in Catalonia. The presence of European firms in Catalonia is very high, trade links are strong, and the Catalan corridor accounts for a high percentage of the transport of goods between Spain and the rest of Europe. It would therefore not be probable that trade barriers would rise again between Catalonia and the countries of the EU. 
However, unlike Scotland, Catalonia is not only a member of the EU, but also of the Euro zone. This is, of course, an open question. The 'status' of an independent Catalonia regarding the EU would depend essentially on political factors. However, the costs of leaving the euro would be very high. Catalan banks would have serious difficulties to access the European Central Bank liquidity mechanisms [see Galí (2013) and Jobst e.a. (2012) about this point]. These mechanisms have been essential in the last years; the Catalan government would face serious difficulties in financing its debt through the markets and, without the access to the mechanisms that the Euro zone provides, it would probably be condemned to default; and if the Catalan currency had to devaluate in relation to the Euro, it would be very difficult to repay the burden of foreign debt.

A scenario of Catalonia outside the Euro is not a sustainable scenario. This is an important point. For many people, the vote in a referendum could crucially depend on whether Catalonia would be excluded from the European Union and the Euro zone.

\section{3) The effects on market efficiency}

The secession of Catalonia would produce two kinds of effects in terms of market efficiency. On the one hand, it could produce market fragmentation. The Catalan and Spanish markets are currently highly integrated. Thus, it is very possible that, as Bell (2010) points out for the case of Scotland and the United Kingdom, some kind of border effect would appear in these currently highly integrated markets, reducing market efficiency. In some areas such as the financial market, market fragmentation could lead to a critical situation. This is probably one of the biggest issues to be discussed in a hypothetical referendum over the independence of Catalonia. Could an independent Catalonia preserve its present financial power? Again, in a very large part, the answer depends on whether Catalonia continues to be part of the EU and the Euro zone.

On the other hand, new regulations could be more pro market efficiency than the current ones in the Spanish state. In some markets like labour or services markets, rigidities are still important, and there is substantial room for improving efficiency (Galí , 2012; Antràs and Ventura, 2012).

\section{4) The allocation of liabilities and assets}

A final relevant point is the allocation of common assets and liabilities. This is a topic generally examined in these processes (Bell 2010; Vaillancourt, 2010), and some authors have studied it for the Catalonia/Spain case (see, among others, Bosch and Espasa, 2012; Sala-i-Martin, 2012a; Tugores, 2013). First of all, it is necessary to specify the scope of liabilities and assets to be considered. State debt is an obvious case. Secondly, different indicators are possible for the allocation. An elementary approach is to allocate it according to population shares. However, other approaches are possible. For instance, Bosch and Espasa (2012) use the share of central government expenditure in some recent period of years. But other arguments, along opposite lines, could obviously be provided.

A special case that is often mentioned is the Social Security Reserve Fund. The portfolio of the Fund largely consists of state debt, so the temptation could exist to propose to consolidate it before allocating state debt. The result would be clearly different if other alternatives, like allocating it according to social contributions, were adopted. 
Finally, there is the allocation of state assets. The Spanish state has the ownership of physical and financial assets. How should these assets be allocated if Catalonia seceded? Which are the assets to be considered? There is no clear answer to this important point, and not many previous experiences elsewhere to draw from. But it seems clear that if a share of total state debt should be assumed by the new sovereign state, the same should happen with total state assets.

The allocation of liabilities and assets is always a political issue. The principle is clear: the new state should assume a share of assets and liabilities from the former common state. But there are not general recipes, and the decisive aspect is, ultimately, whether the separation is the result of a friendly or an unfriendly process.

\section{A CONCLUDING REMARK: A FRIENDLY OR AN UNFRIENDLY PROCESS}

A crucial point to assess the economic and financial effects of the scenario of secession is the path that could lead to it. A process of secession is never a gentleman's contest. Central governments usually refuse for a long time to accept that the fragmentation of the territory could even be considered. Territories that intend to hold a referendum on self-determination usually need a long time for the process, and have to jump many hurdles on the way.

But it is clear that these effects are very different if the secession is the result of an agreement between parts and their conditions are negotiated between them in a friendly way (as it happens in the case of Scotland/United Kingdom and happened before in the case of Quebec/Canada), instead of a traumatic secession. Traumatic here does not necessarily mean violent, but without dialogue, with very polarised positions, with a locked negative to sit around a table by one side and the threat of unilateral pronunciations by the other side.

This is currently the situation in the conflict Catalonia/Spain, where no form of institutional dialogue even exists, and the positions of both sides are far apart. The current subject of conflict still is not secession, but a referendum, and for the moment the doors are absolutely closed not only to accepting to hold it but even to beginning to speak about the proposal.

Even if it is evident that neither in Quebec nor in Scotland the process towards the referendum was short, easy and free of tensions, this is an aspect which is particularly unique to the current situation in Catalonia. And this difference has a strong impact on the economic and financial elements in all the fields we have assessed. It is clear that political conflict could have economic consequences, both for the trade between Catalonia and Spain, for the financial markets and for the EU and euro zone membership issue.

Economic decisions are always strongly determined by expectations about social and political stability, confidence in the institutions and in the rule of law, and perceived security for creditors about the payment of debts and fulfilment of contracts. And in the scenario of secession, all these elements would crucially be affected by the way it is achieved. 
Table 1

Economic Indicators (2012)

\begin{tabular}{|c|c|c|c|}
\hline & Catalonia & Spain & $\%$ Cat/Spain \\
\hline Population (January 2013) & 7.547 .000 & 47.060 .000 & 16,0 \\
\hline \multicolumn{4}{|l|}{ GDP } \\
\hline Total amount (million €) & 198.633 & 1.051 .204 & 18,9 \\
\hline Annual growth (\%) (in real terms) & $-1,0$ & $-1,4$ & \\
\hline Per capita (EU27=100) (PPP) & 116,9 & 97,7 & 119,7 \\
\hline Per capita (EU15=100) (PPP) & 106,7 & 89,0 & \\
\hline \multicolumn{4}{|l|}{ Sectorial Structure of GDP (\%) } \\
\hline Agriculture & 1,3 & 2,5 & \\
\hline Industry & 19,2 & 15,5 & \\
\hline Construction & 7,1 & 8,3 & \\
\hline Services & 64,2 & 65,4 & \\
\hline Taxes & 8,3 & 8,3 & \\
\hline Total & 100,0 & 100,0 & \\
\hline \multicolumn{4}{|l|}{ Good Exports } \\
\hline Total amount (million $€$ ) & 58.322 & 222.644 & 26,2 \\
\hline Variation (\%) & 5,7 & 4,0 & \\
\hline \multicolumn{4}{|l|}{ Employment } \\
\hline Total employees (thousands) & 2.889 & 17.282 & 16,7 \\
\hline Variation (\%) & $-6,2$ & $-4,5$ & \\
\hline \multicolumn{4}{|l|}{ Unemployment } \\
\hline Total unemployment (thousands) & 846 & 5.769 & 14,7 \\
\hline Unemployment Rate & 22,6 & 25,0 & \\
\hline Last figures & & & \\
\hline IV trim. 2013 & 22,3 & 26,0 & \\
\hline III trim. 2013 & 22,8 & 26,0 & \\
\hline \multicolumn{4}{|l|}{ Tourism } \\
\hline Visitors (thousands) & 15.534 & 57.701 & 26,9 \\
\hline Variation (\%) & 3,8 & 2,7 & \\
\hline Total expenditure (million $€$ ) & 12.608 & 55.594 & 22,7 \\
\hline Variation (\%) & 13,8 & 5,7 & \\
\hline
\end{tabular}

Source: Own elaboration from data IDESCAT and INE.

Table 2

Distribution of total public expenditure for levels of government in Spain (1978-2010) (\% of total)

\begin{tabular}{lcccccrrrrr}
\hline & $\mathbf{1 9 7 8}$ & $\mathbf{1 9 8 4}$ & $\mathbf{1 9 9 0}$ & $\mathbf{2 0 0 0}$ & $\mathbf{2 0 0 2}$ & $\mathbf{2 0 0 6}$ & $\mathbf{2 0 0 7}$ & $\mathbf{2 0 0 8}$ & $\mathbf{2 0 0 9}$ & $\mathbf{2 0 1 0 ( P )}$ \\
\hline Central Government & $\mathbf{8 9 , 0}$ & $\mathbf{7 2 , 6}$ & $\mathbf{5 9 , 6}$ & $\mathbf{5 9 , 0}$ & $\mathbf{5 4 , 7}$ & $\mathbf{5 0 , 7}$ & $\mathbf{5 0 , 0}$ & $\mathbf{5 0 , 0}$ & $\mathbf{5 0 , 4}$ & $\mathbf{5 2 , 0}$ \\
$\quad$ Central Administration & 39,1 & 31,9 & 26,2 & 25,7 & 24,4 & 22,2 & 21,7 & 21,4 & 20,7 & 20,4 \\
$\quad$ Social Security Administration & 49,9 & 40,7 & 33,4 & 33,3 & 30,3 & 28,5 & 28,3 & 28,6 & 29,7 & 31,6 \\
Autonomous Governments & - & $\mathbf{1 4 , 4}$ & $\mathbf{2 3 , 9}$ & $\mathbf{2 8 , 3}$ & $\mathbf{3 2 , 3}$ & $\mathbf{3 5 , 9}$ & $\mathbf{3 5 , 9}$ & $\mathbf{3 6 , 4}$ & $\mathbf{3 5 , 7}$ & $\mathbf{3 4 , 6}$ \\
Local Governments & $\mathbf{1 1 , 0}$ & $\mathbf{1 3 , 0}$ & $\mathbf{1 6 , 5}$ & $\mathbf{1 2 , 7}$ & $\mathbf{1 3 , 0}$ & $\mathbf{1 3 , 4}$ & $\mathbf{1 4 , \mathbf { 1 }}$ & $\mathbf{1 3 , 6}$ & $\mathbf{1 3 , 8}$ & $\mathbf{1 3 , 4}$ \\
Total public sector expenditure & $\mathbf{1 0 0 , 0}$ & $\mathbf{1 0 0 , 0}$ & $\mathbf{1 0 0 , 0}$ & $\mathbf{1 0 0 , 0}$ & $\mathbf{1 0 0 , 0}$ & $\mathbf{1 0 0 , 0}$ & $\mathbf{1 0 0 , 0}$ & $\mathbf{1 0 0 , 0}$ & $\mathbf{9 9 , 9}$ & $\mathbf{1 0 0 , 0}$ \\
\hline Source: Own elaboration from data of the Intervención General de la Adminsitración del Estado. & & & & & &
\end{tabular}

(P) Provisional. 
Table 3

Expenditure of Generalitat of Catalonia by functions (\% of total)

\begin{tabular}{lrrrr}
\hline & \multicolumn{2}{c}{2008} & \multicolumn{2}{c}{2012} \\
& \% of total & \% of total & \% of total & \% of total \\
\hline General expenditure & 7,2 & 6,9 & 5,0 & 4,3 \\
Justice, public safety and civil protection & 5,7 & 5,5 & 6,3 & 5,3 \\
Health & 27,2 & 26,2 & 28,0 & 23,8 \\
Education & 17,2 & 16,6 & 17,3 & 14,8 \\
Infrastructures and mobility & 8,6 & 8,3 & 7,5 & 6,4 \\
Protection and social promotion & 6,1 & 5,9 & 8,6 & 7,3 \\
Promotion and regulation of the productive sectors (2) & 5,3 & 5,2 & 8,2 & 7,0 \\
Financial support to local entities & 9,5 & 9,1 & 9,2 & 7,8 \\
Others (1) (2) & 13,2 & 12,7 & 9,9 & 8,5 \\
Public debt interest & & 2,0 & & 5,4 \\
Public debt repayment & 1,7 & & 9,4 \\
Total without debt interest and debt repayment & 100,0 & & 100,0 & \\
Total amount without debt interest and debt repayment (million $€$ ) & $\mathbf{3 3 . 4 9 3 , 8}$ & $\mathbf{3 1 . 5 3 8 , 7}$ & 100,0 \\
Total with debt interest and debt repayment & & $\mathbf{3 4 . 7 5 0 , 0}$ & & $\mathbf{3 7 . 0 3 2 , 5}$ \\
Total amount with debt interest and debt repayment (million $€$ ) & & &
\end{tabular}


Table 4

Revenues of Generalitat of Catalonia ${ }^{1}$ (2012)

\begin{tabular}{|c|c|c|}
\hline & Million $€$ & $\%$ \\
\hline 1. Tax revenues & $17.942,4$ & 73,7 \\
\hline 1.1. Own Taxes & 379,2 & 1,6 \\
\hline 1.2.Fully Ceded Taxes & $2.728,4$ & 11,2 \\
\hline Inheritance Tax & 197,6 & 0,8 \\
\hline Wealth Tax & 240,4 & 1,0 \\
\hline Real Estate Transactions Tax & $1.221,1$ & 5,0 \\
\hline Gamble Tax & 254,0 & 1,0 \\
\hline Vehicles Sales Tax & 114,2 & 0,5 \\
\hline Retail Hydrocarbons $\operatorname{Tax}^{2}$ & 390,0 & 1,6 \\
\hline Energy Tax & 311,1 & 1,3 \\
\hline 1.3.Shared Taxes & $14.834,8$ & 61,0 \\
\hline Personal Income Tax & $7.664,1$ & 31,5 \\
\hline Value Added Tax & $5.219,3$ & 21,4 \\
\hline Tobaco Excise & 857,7 & 3,5 \\
\hline Alcohool Excise & 123,2 & 0,5 \\
\hline Hydrocarbons Excise & 983,0 & 4,0 \\
\hline Excise adjustment & $-12,5$ & $-0,1$ \\
\hline 2. Grants & $1.935,1$ & 8,0 \\
\hline 2.1. From Central Government ${ }^{3}$ & $1.789,9$ & 7,4 \\
\hline Global Sufficiency Fund & $1.765,1$ & 7,3 \\
\hline Fundamental Public Services Guarantee Fund & $-1.065,5$ & $-4,4$ \\
\hline Adjustment for previous years & $1.090,3$ & 4,5 \\
\hline 2.2. Other Grants & 145,2 & 0,6 \\
\hline 3. Other revenues ${ }^{4}$ & $4.455,5$ & 18,3 \\
\hline Total non-financial revenues & $24.333,0$ & 100,0 \\
\hline \multicolumn{3}{|l|}{ Source: Own elaboration from data Generalitat de Catalunya. } \\
\hline \multicolumn{3}{|l|}{1 Budgetary previsions. } \\
\hline \multicolumn{3}{|l|}{2 Surcharge over the central government excise. } \\
\hline \multicolumn{3}{|l|}{3 Not includes Competitiveness Fund. } \\
\hline $\begin{array}{l}4 \text { Includes income from assets, pass through grants from cen } \\
\text { capital grants from central government and other minor reve }\end{array}$ & ernments, & \\
\hline
\end{tabular}


Table 5

Equalization Effect of Autonomous Financing System

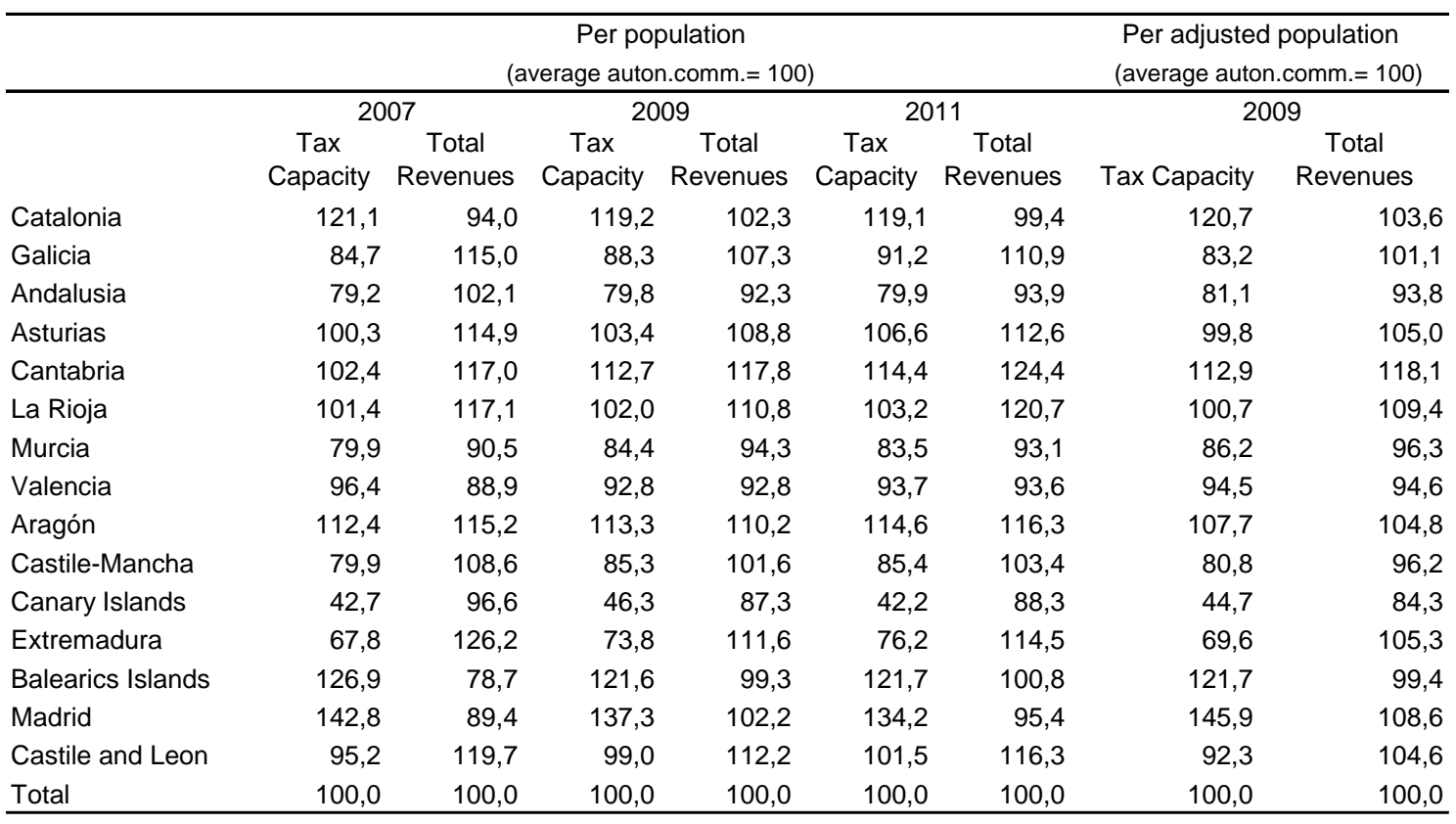

Source: Own elaboration from data Ministerio de Hacienda y Administraciones Públicas.

Table 6

Net fiscal flows of Catalonia with the rest of Spain (\% of Catalan GDP)

\begin{tabular}{|c|c|c|c|c|c|c|}
\hline & 2005 & 2006 & 2007 & 2008 & 2009 & 2010 \\
\hline \multicolumn{7}{|l|}{ Cash-Flow Approach } \\
\hline $\begin{array}{l}\text { Actual Fiscal Flows (without neutralisation) } \\
\text { Neutralised Fiscal Flows }{ }^{1}\end{array}$ & $-9,8 \%$ & $-10,3 \%$ & $-10,7 \%$ & $-5,7 \%$ & $-0,4 \%$ & $-3,0 \%$ \\
\hline Using total expenditure & $-8,3 \%$ & $-7,9 \%$ & $-8,1 \%$ & $-8,5 \%$ & $-8,4 \%$ & $-8,5 \%$ \\
\hline Using total revenue & $-8,8 \%$ & $-8,6 \%$ & $-8,9 \%$ & $-8,4 \%$ & $-6,3 \%$ & $-7,0 \%$ \\
\hline \multicolumn{7}{|l|}{ Benefit Approach } \\
\hline $\begin{array}{l}\text { Actual Fiscal Flows (without neutralisation) } \\
\text { Neutralised Fiscal Flows }{ }^{1}\end{array}$ & $-7,4 \%$ & $-8,0 \%$ & $-8,2 \%$ & $-3,2 \%$ & $2,1 \%$ & $-0,4 \%$ \\
\hline Using total expenditure & $-6,0 \%$ & $-5,6 \%$ & $-5,6 \%$ & $-5,9 \%$ & $-5,8 \%$ & $-5,8 \%$ \\
\hline Using total revenue & $-6,3 \%$ & $-6,1 \%$ & $-6,2 \%$ & $-5,3 \%$ & $-4,3 \%$ & $-4,8 \%$ \\
\hline
\end{tabular}

Source: Own elaboration from data Generalitat de Catalunya.

1 'As if' the central government budget was balanced. 


\section{REFERENCES}

Aghion, Philippe and Durlauf, Steven (eds.) (2005), Handbook of Economic Growth (vol. 1), Elsevier, Amsterdam.

Alesina, Alberto (2003), "The size of countries: Does it matter?", Journal of European Economic Association, April-May 2003, pp. 301-316.

Alesina, Alberto and Spolaore, Enrico (1997), "On the number and size of nations", Quarterly Journal of Economics, 112 (4), pp. 1027-1056.

Alesina, Alberto and Spolaore, Enrico (1997), The size of nations, MIT Press, Cambridge (Mass.).

Alesina, Alberto, Spolaore, Enrico and Wacziarg, Roman (2005), "Trade, Growth and the Size of Countries”, in Aghion and Durlauf (2005), pp.1499-1542.

Amat, Oriol (2013), "Radiografía del tejido empresarial catalán y posibles impactos del debate independentista", in Amat e.a. (2013), pp. 11-25.

Amat, Oriol; Feito, José Luis; Fernández, Donato; Pich, Valentín; Polo, Clemente; Semur, Almudena; Trigo, Joaquín and Tugores, Juan (2013), La cuestión catalana, hoy, Instituto de Estudios Económicos, Madrid, 2013.

Anderson, James and Van Wincoop, Eric (2001), "Gravity with Gravitas: A Solution to the Border Puzzle”, Working Paper no. 8079 (National Bureau of Economic Research), Cambridge (Mass.).

Antràs, Pol (2012), "La desagradable aritmética de la independencia: respuesta a la entrada de José Vicente Rodríguez Mora", Nada es Gratis (fedeablogs), 14-10-21012.

Antràs, Pol and Ventura, Jaume (2012), "Dos més dos són mil”, Col·lectiu Wilson (blog), 23-11-2012.

Bakke, K.M. and Wibbels, E. (2006), "Diversity, Disparity, and civil conflict in federal states", World Politics, October 2008, pp.305-321.

Baró, Ezequiel and Bosch, Núria (1996), "Fluxos comercials i fiscals a BadenWürttemberg, Lombardia i Catalunya: una anàlisi comparativa", Estudis Econòmics, núm 1, Departament d'Economia i Finances, Generalitat de Catalunya.

Becker, Gary (2012), "Breakup of Countries: No Economic Disaster", becker-posnerblog.com, 04-12-2012.

Bell, David (2010), "Staying together?: Scotland and the rest of the United Kingdom", in Bosch e. a. (2010), pp. 389-403.

Bordignon, Massimo (2010), "Comment" [Spolaore (2010)], in Bosch e.a. (2010), pp. 351-356.

Bosch, Núria (2013), Anàlisi econòmica del procés d'independència de Catalunya, Fundació Josep Irla, Barcelona, 2013.

Bosch, Núria; Espasa, Marta; and Solé-Ollé, Albert (eds.) (2010), The Political Economy of Inter-Regional Fiscal Flows, Edward Elgar, Cheltenham (UK), 2010. 
Bosch, Núria and Espasa, Marta (2012), "Viabilitat de Catalunya com a estat. Anàlisi de la hisenda pública“, in Els reptes econòmics de la Unió Europea. Com afectarà la nova integració fiscal a les Comunitats Autònomes?, Fundació CatDem, Barcelona, 2012.

Castells, Antoni (1979), "Balança fiscal de Catalunya: incidència fiscal de l'actuació de l'Estat", Revista Econòmica (Banca Catalana), setembre 1979.

Castells, Antoni (1998), "Integració monetària i desequilibris territorials a la Unió Europea”, Revista Econòmica (Banca Catalana), març 1998.

Castells, Antoni and Parellada, Martí (1983a), Els fluxos econòmics de Catalunya amb la resta d'Espanya i la resta del món. La balança de pagaments de Catalunya 1975, Instritut d'Estudis Catalans, Barcelona.

Castells, Antoni and Parellada, Martí (1983b), "Los flujos económicos de Cataluña con el exterior", in La economía de Cataluña, hoy y mañana, Banco de Bilbao, Bilbao.

Castells, Antoni; Barberán, Ramón; Bosch, Núria; Espasa, Marta; Rodrigo, Fernando; and Ruiz-Huerta, Jesús (2000), Las balanzas fiscales de las Comunidades Autónomas (1991-1996), Ariel, Barcelona.

Cuadras Morató, Xavier and Guinjoan, Modest (2012), “Una aproximació a l'impacte sobre el VAB català de la reducció dels fluxos comercials entre Catalunya i la resta d'Espanya", Revista Econòmica de Catalunya, no. 65, 2012.

Cuadras i Morató, Xavier (2012), "Algunes reflexions sobre la independència de Catalunya i l'economia dels catalans", in Els reptes econòmics de la Unió Europea. Com afectarà la nova integració fiscal a les Comunitats Autònomes?, Fundació CatDem, Barcelona, 2012.

De la Fuente, Angel (2012), “Cisne negro o pollo del montón”, El País, 07-10-2012.

De la Fuente, Angel and Rodríguez Mora, José V. (2012), "Las cuentas de la lechera", El País, 24-09-2012.

Departament d'Economia i Finances (Generalitat de Catalunya) (2005), La balança fiscal de Catalunya amb l'Administració central, Grup de treball per a l'actualització de la balança fiscal de Catalunya, Barcelona.

Departament d'Economia i Finances (Generalitat de Catalunya) (2008), Resultat de la balança fiscal de Catalunya amb l'Administració central 2002-2005, Grup de treball per a l'actualització de la balança fiscal de Catalunya, Barcelona. (published in Monografies, núm 10, Departament d'Economia i Finances, "Metodologia i càlcul de la balança fiscal de Catalunya amb l'Administració central 2002-2005").

Departament d'Economia i Coneixement (Generalitat de Catalunya) (2012), Resultat de la balança fiscal de Catalunya amb el sector públic central 2006-2009, Barcelona.

Departament d'Economia i Coneixement (Generalitat de Catalunya) (2013), La balança fiscal de Catalunya amb l'Administració central 2010, Barcelona.

Eaton, Jonathan and Kortun, Samuel (2002), "Technology, Geography, and Trade", Econometrica, September 2002, pp. 1741-1779. 
Galí, Jordi (2012), “La independencia, per fer què?, La Vanguardia, 14-10- 2012.

Galí, Jordi (2013), “Estat propi i euro”, Col.lectiu Wilson (blog), 19-03-2013.

Garicano, Luis (2011), "El coste comercial de la separación”, Nada es Gratis (fedeablogs), 26-06-2011.

Ghemawat, Pankaj (2011a), World 3.0 (Global Prosperity and to Achieve it), The Harvard Business Review Press, Boston.

Ghemawat, Pankaj (2011b), "Coste comercial de la separación”, La Vanguardia, 1906-2011.

Guinjoan, Modest and Cuadras Morató, Xavier (2011), Sense Espanya (Balanç econòmic de la independència), Pòrtic, Barcelona.

Inman, Robert (2008), "Federalism's values and the value of federalism", Working Paper no. W13735 (National Bureau of Economic Research), Cambridge (Mass.).

Jobst, Clemens; Handig, Martin; and Holzfeind, Robert (2012), "Understanding TARGET2: The Eurosystem's Euro Payment System from an Economic and Balance Sheet Perspective", Monetary Policy \& The Economy (Austrian National Bank), Q!/12, pp. 81- 91.

López-Casasnovas, Guillem (2013), "El Déficit Fiscal de una Comunidad Autónoma con la Administración Central: ¿de qué estamos hablando? (I and II)", Nada es Gratis (fedeablogs), 29-05-2013.

McCallum, John (1995), "National Borders Matter: Canada-US Regional Trade Patterns", American Economic Review, June 1995, pp. 615-623.

Ministerio Economía y Hacienda (2008), Las balanzas fiscales de las CC.AA. españolas con las Administraciones Públicas centrales 2005, julio 2008.

Paluzie, Elisenda (2010), "The costs and benefits of staying together: The catalan case in Spain”, in Bosch e. a. (2010), pp. 357-370.

Petit Fontseré, Jordi (1965), "Unas notas sobre la actuación del Sector Público y las relaciones entre Cataluña y el resto de España”, Moneda y Crédito, diciembre 1965, pp. 61-76.

Rodríguez Mora, José V. (2012), "Portugal, España, Cataluña. Amics per sempre (I and II)", Nada es Gratis (fedeablogs), 12 and 14-10-21012.

Rodríguez Mora, José V. (2012), "La desagradable lógica de la independencia: respuesta a una respuesta de Pol Antràs, Nada es Gratis (fedeablogs), 19-10-21012.

Ros Hombravella, Jacint and Montserrat, Antoni (1967), L'aptitud financera de Catalunya, Edicions 62, Barcelona.

Sala i Martin, Xavier (2012a), "Dos imágenes que demuestran que Catalunya independiente estará en la UE", Col·lectiu Wilson (blog), 4-november-2012.

Sala i Martin, Xavier (2012b), "El dividend fiscal de la independència", Col-lectiu Wilson (blog), 21-11-2012. 
Spolaore, Enrico (2010), "Federalism, regional redistribution and country stability", in Bosch e.a. (2010), pp. 329-350.

Trias Fargas, Ramon (1960), La balanza de pagos interior, Sociedad de Estudios y Publicaciones, Madrid.

Tugores, Juan (2013), "Perspectivas económicas: realidades, incertidumbres y temas en la agenda", in Amat e.a. (2013), pp. 141-154.

Vaillancourt, François (2010), "The costs and benefits of constitucional options for Québec and Canada”, in Bosch e.a. (2010), pp. 371-388.

Vaubel, Robert (2013), "The Political Economy of Secesión in the European Union", 09-04-2013.

Vilalta, Maite (2013), “Análisis del modelo de financiación autonómica del 2009: revisión o final de ciclo", en "Propuestas para la reforma de la financiación autonómica", Revista del Instituto de Estudios Económicos, núms.1-2/2013.

Zabalza, Antoni (2012), “Malentendidos del saldo fiscal catalán”, El País, 19-11-2012.

Zabalza, Antoni (2013), "Cuatro reflexiones sobre el saldo fiscal catalán (I and II)", Nada es Gratis (fedeablogs), 05-04-2013. 